\title{
Pengaruh Karakteristik Perusahaan, Tata Kelola Perusahaan dan Atribut Audit Terhadap Luas Pengungkapan Risiko
}

\author{
Shintya Dewi \\ Universitas Katolik Soegijapranata \\ shintya51@gmail.com
}

\begin{abstract}
The purpose of this research is to analyze the influence of company characteristic such as leverage, company size, and industry type and corporate governance in the form of audit committee, number of board of commissioner and frequency of board meeting then audit attribute is auditor quality to risk disclosure. Risk disclosure is a disclosure made by a company that may impact and pose a threat to the company's future performance. To explain the relationship between variables in this study, used agency theory and stakeholder theory. The population of this study are all companies listed in Indonesia Stock Exchange 2012-2016. The total sample of 568 companies was determined by Purposive Sampling method. This research uses content analysis method to calculate risk disclosure. There are 37 items used in this study. The results showed that firm size, audit committee, board meeting frequency, auditor quality had significant effect on risk disclosure, while leverage, number of board of commissioner and industry type had no significant effect on risk disclosure.
\end{abstract}

Keywords: risk disclosure, corporate characteristics, corporate governance and auditor quality.

\begin{abstract}
Abstrak
Tujuan dari penelitian ini adalah untuk menganalisis pengaruh karakteristik perusahaan seperti leverage, ukuran perusahaan, dan jenis industri serta tata kelola perusahaan berupa komite audit, jumlah dewan komisaris dan frekuensi rapat dewan komisaris kemudian ada atribut audit yaitu kualitas auditor terhadap pengungkapan risiko. Pengungkapan risiko adalah pengungkapan yang dilakukan oleh perusahaan yang mungkin berdampak dan menjadi ancaman pada kinerja perusahaan di masa yang akan datang. Untuk menjelaskan hubungan antar variabel dalam penelitian ini, digunakan teori keagenan dan teori stakeholder. Populasi penelitian ini adalah seluruh perusahaan yang terdaftar di Bursa Efek Indonesia tahun 2012-2016. Total sampel yang berjumlah 568 perusahaan ditentukan dengan metode Purposive Sampling. Penelitian ini menggunakan metode konten analisis untuk menghitung pengungkapan risiko. Terdapat 37 item yang digunakan dalam penelitian ini. Hasil penelitian menunjukan bahwa ukuran perusahaan, komite audit, frekuensi rapat dewan komisaris, kualitas auditor berpengaruh signifikan terhadap pengungkapan risiko, sedangkan leverage, jumlah dewan komisaris dan jenis industri tidak berpengaruh signifikan terhadap pengungkapan risiko.
\end{abstract}

Kata kunci: pengungkapan risiko, karakteristik perusahaan, tata kelola perusahaan dan kualitas auditor. 


\section{PENDAHULUAN}

Pengungkapan risiko merupakan salah satu aspek yang termasuk dalam tuntutan pengungkapan tersebut. Dengan adanya pengungkapan risiko yang dilakukan oleh perusahaan, maka stakeholders menjadi lebih tertarik untuk ikut berkontribusi dalam setiap risiko yang dihadapi oleh perusahaan. Badan regulator di Indonesia membuat peraturan tentang pengungkapan risiko pada laporan tahunan yang disusun oleh perusahaan, diantaranya adalah PSAK No. 60 Instrumen Keuangan (Revisi 2014), mengenai instrumen keuangan: Pengungkapan. Peraturan tersebut menjelaskan bahwa perusahaan harus mengungkapkan informasi laporan keuangan agar pemegang saham dapat mengevaluasi kinerja keuangan perusahaan berdasarkan posisi keuangan perusahaan. Tidak hanya itu namun disini pengguna dapat menganalisis risiko-risiko apa saja yang timbul dan bagaimana manajemen melakukan pengelolaan terhadap risiko terebut.

Peraturan mengenai pengungkapan risiko juga terdapat pada Peraturan Otoritas Jasa Keuangan Nomor 29/POJK.04/2016 tentang Laporan Tahunan Emiten atau Perusahaan Publik, bahwa dalam rangka meningkatkan kualitas keterbukaan informasi oleh Emiten atau Perusahaan Publik dalam Laporan Tahunan Emiten atau Perusahaan Publik, perlu menyempurnakan peraturan mengenai Laporan Tahunan Emiten atau Perusahaan Publik dengan menetapkan Peraturan Otoritas Jasa Keuangan tentang Laporan Emiten atau Perusahaan Publik.

Bank Indonesia juga memiliki ketentuan terkait dengan permasalahan pengungkapan risiko seperti yang tertuang dalam Peraturan Bank Indonesia Nomor 14/14/PBI/2012 tentang Transparansi dan Publikasi Laporan Bank. Peraturan tersebut mengharuskan Bank untuk menyusun Laporan Tahunan paling kurang mencakup jenis risiko dan potensi kerugian (risk exposures) yang dihadapi Bank serta praktek manajemen risiko paling kurang untuk risiko kredit, risiko pasar, risiko potensial, risiko likuiditas, risiko strategik, risiko reputasi, risiko kepatuhan, dan risiko hukum (Utomo dan Chariri, 2014).

Beberapa faktor yang mempengaruhi tingkat pengungkapan risiko perusahaan yaitu leverage, ukuran perusahaan, komite audit, kualitas auditor, jumlah dewan komisaris, frekuensi rapat dewan komisaris dan jenis industri. Utomo dan Chariri(2014) menguji pengaruh leverage terhadap pengungkapan risiko perusahaan menemukan bahwa leverage berpengaruh positif terhadap pengungkapan risiko perusahaan. Wardhana dan Cahyonowati (2013) melakukan uji mengenai pengaruh ukuran perusahaan terhadap pengungkapan risiko perusahaan menemukan bahwa ukuran perusahaan berpengaruh positif pada pengungkapan risiko perusahaan. Oktarina (2015) menemukan komite audit berpengaruh positif terhadap pengungkapan risiko perusahaan. Al-Shammari (2014) memberi bukti kualitas auditor berpengaruh positif terhadap pengungkapan risiko perusahaan. Suhardjanto et al., (2012) menemukan bahwa jumlah dewan komisaris berpengaruh positif terhadap pengungkapan risiko perusahaan. Suhardjanto et al., (2012) melaporkan frekuensi rapat dewan komisaris berpengaruh positif terhadap pengungkapan risiko perusahaan. Penelitian ini menguji kembali variabel-variabel yang mempengaruhi pengungkapan risiko perusahaan dengan menggabungkan berbagai penelitian yang pernah dilakukan sebelumnya. Tujuannya adalah untuk mengetahui konsistensi hasil penelitian.

\section{TINJAUAN LITERATUR DAN PERUMUSAN HIPOTESIS}

\section{Pengungkapan Risiko}

Teori agensi mengemukakan bahwa hubungan keagenan adalah sebagai suatu kontrak dimana satu atau lebih principal (pemilik) menggunakan orang lain atau agent (manajer) untuk menjalankan aktifitas perusahaan yang melibatkan pendelegasian beberapa wewenang 
pengambilan keputusan dari principal kepada agent (Jensen dan Meckling, 1976). Hubungan yang tercipta ini muncul atas dasar saling membutuhkan antara kedua belah pihak untuk memenuhi masing-masing kepentingan yang berbeda. Dengan adanya perbedaan kepentingan yang muncul, seringkali menimbulkan masalah atau konflik antara kedua belah pihak. Konflik kepentingan inilah yang menjadi dasar munculnya asimetri informasi antara agent dan principal. Menurut Utomo dan Chariri (2014) tujuan utama pengungkapan risiko adalah untuk mengurangi asimetri informasi yang terjadi antara agent dan principal.

Pengungkapan risiko merupakan salah satu aspek penting yang harus dilakukan oleh perusahaan. Dengan adanya pengungkapan risiko yang dilakukan perusahaan dalam laporan tahunan maka perusahaan sudah melakukan pengelolaan terhadap risiko. Perusahaan sebaiknya memberikan informasi mengenai risiko dan mengungkapkannya secara jelas dan akurat. Dengan pengungkapan risiko yang jelas dan akurat maka principal dan agent bisa mengambil keputusan dengan baik. Artinya semakin sering perusahaan melakukan pengungkapan risiko yang jelas dan akurat maka pasar juga akan semakin percaya dengan informasi mengenai risiko apa yang terjadi dan bagaimana cara menanganinya.

\section{Leverage dan Pengungkapan Risiko}

Mardiyanto (2008) dalam Doi dan Harto (2014) menyatakan bahwa leverage berasal dari kata lever yang berarti pengungkit, apabila dihubungkan dengan manajemen keuangan, biaya tetap (yang berasal dari aktivitas operasi dan keuangan) dapat dipandang sebagai leverage karena sanggup untuk menghasilkan atau mengungkit laba yang lebih besar dan begitu juga sebaliknya, leverage juga berpotensi menimbulkan kerugian yang besar juga.

Menurut teori keagenan, kreditur dari perusahaan yang memiliki tingkat utang tinggi dalam struktur modal dapat memaksa perusahaan untuk mengungkapkan informasi lebih besar (Amran et al., 2009). Menurut Utomo dan Chariri (2014) hal ini dikarenakan perusahaan dengan tingkat utang yang tinggi biasanya lebih spekulatif dan berisiko, sehingga pengungkapan yang lebih luas atas informasi risiko dibutuhkan guna mengurangi asimetri informasi antara agent dan principal. Berdasarkan argumen dan temuan empiris diatas maka hubungan antara leverage dan pengungkapan risiko dapat dinyatakan sebagai berikut:

\section{H1 : Leverage berpengaruh positif terhadap luas pengungkapan risiko}

\section{Ukuran Perusahaan dan Pengungkapan Risiko}

Ukuran perusahaan merupakan nilai yang menunjukan besar kecilnya perusahaan (Taures, 2011). Ada beberapa instrumen yang digunakan untuk mengukur besarnya ukuran perusahaan. Contohnya adalah total penjualan, total aset, jumlah karyawan dan nilai kapitalisasi pasar. Jika semakin besar total penjualan, total aset, jumlah karyawan dan nilai kapitalisasi tersebut maka semakin besar pula ukuran perusahaan.

Ukuran perusahaan merupakan variabel paling penting dalam menjelaskan variasi pengungkapan (Al-Shammari, 2014). Perusahaan dengan ukuran lebih besar akan lebih terlihat dan menarik perhatian para pemegang saham. Perusahaan tersebut akan menganggap bahwa pengungkapan risiko sebagai cara untuk meningkatkan reputasi perusahaan melalui sistematika pengungkapan (Wardhana, 2013). Berdasarkan argumen diatas maka hubungan antara ukuran perusahaan dan pengungkapan risiko dapat dinyatakan sebagai berikut:

H2 : Ukuran perusahaan berpengaruh positif terhadap luas pengungkapan risiko.

\section{Jenis Industri dan Pengungkapan Risiko}

Jenis industri menunjukkan keterlibatan perusahaan ke dalam industri-industri tertentu sesuai dengan karakteristik kegiatan usaha yang dioperasikan oleh perusahaan (Taures, 
2011). Perusahaan yang digolongkan sebagai high profile industry merupakan perusahaan yang memiliki tingkat sensitivitas tinggi terhadap lingkungan dan memiliki tingkat persaingan yang lebih berat. Sedangkan perusahaan dengan low profile industry hanya memiliki aktivitas operasi yang lebih sederhana sehingga tingkat toleransi kegagalan juga lebih tinggi dan jauh dari sorotan masyarakat. Industri yang dijalankan oleh perusahaan akan menentukan karakteristik perusahaan, bagaimana perusahaan beroperasi, serta peraturan dan ketentuan yang harus ditaati oleh perusahaan tersebut.

Perusahaan yang beroperasi di industri yang berbeda diharapkan dapat mengalami berbagai jenis risiko. Suatu industri dapat dikenakan peraturan khusus karena sifatnya, sehingga meningkatkan eksposur risiko perusahaan yang sesuai dengannya. Menurut Brammer et al (2008) dalam Utomo dan Chariri (2014) perusahaan yang termasuk dalam high profile industry lebih cenderung untuk mengungkapkan informasi yang lebih dari pada perusahaan low profile industry. Hal tersebut didukung dengan teori keagenan yang menjelaskan bahwa principal akan meminta informasi yang lebih kepada agent yang berhubungan dengan asimetri informasi diantara keduanya tentang risiko yang dihadapi oleh perusahaan. Berdasarkan argumen dan temuan empiris diatas maka hubungan antara jenis industri dan pengungkapan risiko dapat dinyatakan sebagai berikut:

\section{H3 : Jenis industri berpengaruh positif terhadap luas pengungkapan risiko}

\section{Komite Audit dan Pengungkapan Risiko}

Komite audit bertugas dan bertanggung jawab untuk memberikan pendapat kepada dewan komisaris mengenai laporan atau hal-hal lain yang disampaikan direksi (Oktarina, 2015). Menurut Mubarok dan Rohman (2013) dalam teori keagenan, komite audit sebagai komite penunjang dewan komisaris diperkirakan dapat mempengaruhi praktik pengungkapan risiko perusahaan. Menurut Oktarina (2015) komite audit memiliki wewenang untuk melaksanakan dan mengesahkan penyelidikan terhadap masalah-masalah di dalam cakupan tanggung jawabnya. Komite audit juga sebagai alat dimana perusahaan dapat menghindari kecurangan dalam pelaporan keuangan dan memantau kinerja manajemen.

Dalam teori agensi, dijelaskan bahwa konflik keagenan yang timbul sebagai akibat dari pemisahan tujuan dan kepentingan antara pihak agent dan prinsipal dapat mengakibatkan praktik kecurangan atau manipulasi informasi yang dilakukan oleh manajemen. Dengan adanya surat edarasn Bapepam SE-03/PM/2000 tanggal 5 Mei 2000, Bapepam mensyaratkan pembentukan komite audit pada perusahaan publik Indonesia terdiri dari sedikitnya tiga orang anggota dan diketuai oleh Komisaris Independen perusahaan dengan dia orang eksternal yang independen terhadap perusahaan serta menguasai dan memiliki latar belakang dibidang akuntansi dan keuangan. Berdasarkan argumen dan temuan empiris diatas maka hubungan antara komite audit dan pengungkapan risiko dapat dinyatakan sebagai berikut:

\section{H4 : Komite audit berpengaruh positif terhadap luas pengungkapan risiko}

\section{Jumlah Dewan Komisaris dan Pengungkapan Risiko}

Dewan komisaris memegang peranan penting dalam pelaksanaan good corporate governance (tata kelola yang baik) dalam perusahaan. Dewan komisaris memiliki tugas untuk menjamin pelaksanaan strategi perusahaan serta mengawasi manajemen dalam mengelola perusahaan. Dewan komisaris memiliki fungsi penting, dimana dewan komisaris merupakan wakil dari para pemegang saham dengan menyampaikan laporan pertanggungjawaban pengawasan atas pengelolaan persahaan oleh direksi.

Menurut Abeysekera (2008) dalam Suhardjanto et al., (2012) jumlah dewan komisaris yang dinilai efektif apabila berada pada jumlah antara lebih dari lima orang dan kurang dari 
14 orang. Berdasarkan teori keagenan, menyatakan bahwa keefektifan mekanisme corporate governance salah satunya ditentukan oleh besarnya ukuran dewan komisaris yang dapat mengurangi biaya agensi (Linda, 2012). Susunan dewan yang lebih besar akan lebih kuat, karena dapat membuat koordinasi, komunikasi dan pengambilan keputusan yang lebih praktiks dibandingan dengan susunan dewan komisaris yang kecil. Apabila ukuran dewan komisaris kecil, maka akan menyebabkan kekurangan keahlian dan membuat biaya keagenan cukup tinggi, seingga mempengaruhi kemampuan dewan komisaris dalam melaksanakan tanggungjawabnya yaitu mengenai tata kelola perusahaan. Berdasarkan argumen dan temuan empiris diatas maka hubungan antara jumlah dewan komisaris dan pengungkapan risiko dapat dinyatakan sebagai berikut:

\section{H5 : Jumlah dewan komisaris berpengaruh positif terhadap luas pengungkapan} risiko

\section{Frekuensi Rapat Dewan Komisaris dan Pengungkapan Risiko}

Frekuensi rapat dewan komisaris adalah jumlah rapat yang dilakukan oleh dewan komisaris suatu perusahaan selama periode satu tahun. Menurut Brick dan Chidambaran (2007) dalam Suhardjanto et al., (2012) kinerja perusahaan menjadi semakin meningkat seiring dengan semakin banyaknya frekuensi rapat yang diselenggarakan anggota dewan komisaris.

Menurut PBI Nomor : 8/14/PBI/2006 dewan komisaris wajib menyelenggarakan rapat secara berkala sekurang-kurangnya empat kali dalam setahun. Penelitian yang dilakukan Vafeas et al (2003) dalam Suhardjanto et al., (2012) menunjukan jika semakin banyak frekuensi rapat yang diselenggarakan dewan komisaris maka semakin meningkatkan kinerja perusahaan. Sehingga ketika kinerja perusahaan meningkat maka akan mendorong perusahaan untuk melakukan pengungkapan yang lebih luas dalam hal pengungkapan risiko di laporan tahunan perusahaan. Berdasarkan argumen dan temuan empiris diatas maka hubungan antara frekuensi rapat dewan komisaris dan pengungkapan risiko dapat dinyatakan sebagai berikut:

\section{H6 : Frekuensi rapat dewan komisaris berpengaruh positif terhadap luas pengungkapan risiko}

\section{Kualitas Auditor dan Pengungkapan Risiko}

Pada penelitian terdahulu kantor akuntan publik dibedakan menjadi dua klasifikasi, pertama adalah KAP Big Four yang merupakan kantor akuntan publik besar, terkenal dan tersebar diseluruh negara. Dan yang kedua adalah KAP non-Big Four dimana kantor akuntan publiknya kecil dan beroperasi hanya di wilayah domestik. Kualitas auditor eksternal mempengaruhi kualitas hasil audit perusahaan karena keahlian yang mereka miliki (Agustina dan Ratmono, 2014).

Perusahaan dengan biaya agensi tinggi cenderung memiliki kontrak dengan KAP yang memiliki kualitas tinggi seperti KAP Big Four (Jensen dan Meckling, 1976). KAP yang lebih besar dan terkenal ini cenderung mendorong perusahaan untuk mengungkapkan informasi lebih lanjut untuk menjaga reputasi KAP dan menghindari biaya reputasi untuk mereka (Oliveira et al., 2011). Hal ini sejalan dengan teori keagenan, dimana KAP yang besar cenderung untuk memberikan jaminan lebih kepada para pemegang saham sehingga akan mengurangi biaya pemantauan (monitoring cost) yang dikeluarkan oleh principal (Mokhtar dan Mellett, 2013). Berdasarkan argumen dan temuan empiris diatas maka hubungan antara kualitas auditor dan pengungkapan risiko dapat dinyatakan sebagai berikut:

H7 : Kualitas auditor berpengaruh positif terhadap luas pengungkapan risiko. 


\section{METODA PENELITIAN}

\section{Populasi dan Sampel}

Populasi yang digunakan dalam penelitian ini adalah seluruh perusahaan yang terdaftar di Bursa Efek Indonesia. Metode pemilihan sampel dalam penelitian ini ditentukan berdasarkan metode purposive sampling. Pengambilan sampel dalam penelitian ini dilakukan secara purposive sampling yang merupakan cara penarikan sampel berdasarkan kriteria spesifik yang ditetapkan peneliti. Tabel 3.1 menampilkan secara detail kriteria pengambilan sampel. Jumlah observasi yang tersedia untuk pengujian hipotesis adalah 1.072 tahun perusahaan.

Tabel 3.1

Kriteria Pengambilan Sampel

\begin{tabular}{|l|l|l|l|l|l|l|}
\hline Kriteria Pengambilan Sampel & $\mathbf{2 0 1 2}$ & $\mathbf{2 0 1 3}$ & $\mathbf{2 0 1 4}$ & $\mathbf{2 0 1 5}$ & $\mathbf{2 0 1 6}$ & Total \\
\hline $\begin{array}{l}\text { Jumlah perusahaan yang terdaftar di BEI } \\
\begin{array}{l}\text { Laporan tahunan tidak tersedia dari } \\
\text { sumber yang digunakan }\end{array}\end{array}$ & 463 & 486 & 509 & 525 & 539 & 2.522 \\
\hline $\begin{array}{l}\text { Data yang dibutuhkan tidak tersedia di } \\
\text { laporan tahunan }\end{array}$ & $(23)$ & $(4)$ & $(8)$ & $(10)$ & $(10)$ & $(35)$ \\
\hline $\begin{array}{l}\text { Laporan keuangan yang tersedia dalam } \\
\text { dollar AS }\end{array}$ & $(65)$ & $(78)$ & $(82)$ & $(84)$ & $(85)$ & $(394)$ \\
\hline Total Sampel & 162 & 183 & 214 & 264 & 249 & 1.072 \\
\hline
\end{tabular}

\section{Sumber Data}

Data dalam penelitian ini menggunakan data sekunder. Data sekunder yaitu data yang diperoleh peneliti dari sumber lain yang sudah dipublikasikan. Data dalam penelitian ini adalah laporan tahunan (annual report) yang telah diaudit dalam laporan keuangan periode 2012-2016. Sumber data yang digunakan untuk penelitian ini diperoleh dari data observasi yang ada diwebsite Bursa Efek Indonesia (www.idx.co.id), website perusahaan, serta website Indonesia Capital Market Directory (www.ticmi.co.id).

\section{Definisi Operasional dan Pengukuran Variabel}

\section{Luas Pengungkapan Risiko}

Variabel dependen yang digunakan adalah pengungkapan risiko. Pengungkapan risiko merupakan pemberian informasi kepada stakeholders melalui laporan tahunan mengenai potensi kesempatan dan/atau hambatan maupun eksposur pada strategi, tindakan dan kinerja perusahaan yang telah atau akan berpengaruh pada perusahaan (Linsley dan Philip, 2006). Risiko yang dimaksud adalah risiko secara umum, tidak spesifik pada jenis risiko tertentu. Penilaian didasarkan pada tabel pengelompokan risiko yaitu diberi nilai 1 (satu) jika perusahaan melakukan pengungkapan risiko, dan sebaliknya diberi nilai 0 (nol) jika perusahaan tidak melakukan pengungkapan risiko. Selanjutnya tingkat pengungkapan risiko dinilai dengan proporsi pengungkapan yang dilakukan terhadap total pengungkapan.

$$
\text { Pengungkapan Risiko }=\frac{\sum \text { Item Pengungkapan Risiko yang dilakukan Perusahaan }}{\sum \text { Total Item Pengungkapan Risiko }}
$$




\section{Leverage (X1)}

Leverage adalah tingkat hutang yang dimiliki oleh suatu perusahaan dalam jumlah tertentu dengan adanya syarat berupa jaminan kepada kreditur dan merupakan suatu instrumen yang digunakan untuk mengukur seberapa banyak penggunaan hutang sebagai pembiayaan investasi. Tingkat leverage diukur dengan menggunakan debt to equity ratio atau DER. Rumus ini digunakan sebagai proksi risiko dengan mengikuti (Amran et al., 2009). Formula yang digunakan untuk mengukur debt to equity ratio adalah :

$$
\text { Debt to Equity Ratio (DER) }=\frac{\text { Total kewajiban }}{\text { Total Ekuitas }}
$$

\section{Ukuran Perusahaan (X2)}

Ukuran perusahaan (Size) merupakan tingkat identifikasi besar atau kecilnya suatu perusahaan. Ukuran perusahaan dinilai dengan log of total assets, dimana pengukuran ini digunakan untuk mengurangi perbedaan signifikan antara ukuran perusahaan yang terlalu besar dengan ukuran perusahaan yang terlalu kecil, oleh karena itu nilai total aset dibentuk menjadi logaritma natural. Hal ini bertujuan agar data total aset terdistribusi normal. Ukuran perusahaan diukur dengan menggunakan log natural dari total aset (Al-Shammari, 2014).

\section{Jenis Industri (X3)}

$$
\text { Size }=\text { Natural Log of Total Assets }
$$

Jenis industri adalah penggolongan perusahaan ke dalam industri-industri tertentu berdasarkan karakteristik kegiatan yang dilakukan oleh perusahaan. Jenis industri digolongkan menjadi dua macam, yaitu high profile industry dan low profile industry (Taures, 2011). Jenis industri diukur dengan menggunakan variabel dummy. Perusahaan dengan high profile industry yang bergerak dibidang minyak dan pertambangan, kimia, perhutanan, kertas, otomotif, penerbangan, agribisnis, tembakau dan rokok, produk, makanan dan minuman, media dan komunikasi, energi (listrik), engineering, kesehatan, transportasi dan pariwisata (Zuhroh dan Sukmawati, 2003) diberikan nilai 1. Namun, perusahaan dengan low profile industry yang bergerak dibidang bangunan, keuangan dan perbankan, pemasok alat-alat kesehatan, properti, perusahaan pengencer, tekstil dan produk tekstil, produk personal, dan produk rumah tangga makan diberikan nilai 0 .

\section{Komite Audit (X4)}

Komite audit merupakan komite yang dibentuk oleh dewan komisaris dan salah satu anggotanya diharuskan berasal dari anggota komisaris independen (Utomo dan Chariri, 2014). Komite audit diukur dengan menghitung jumlah anggota komite audit yang terdapat dalam laporan tahunan perusahaan di bagian tata kelola.

\section{Jumlah Dewan Komisaris (X5)}

Jumlah dewan komisaris merupakan banyaknya atau jumlah anggota yang menjabat menjadi dewan komisaris. Variabel ini diukur dengan cara menghitung jumlah seluruh anggota dewan komisaris yang dimiliki perusahaan baik yang berasal dari dalam perusahaan maupun luar perusahaan atau independen Suhardjanto et al., (2012).

\section{Frekuensi Rapat Dewan Komisaris (X6)}

Frekuensi rapat dewan komisaris adalah jumlah rapat internal yang diadakan oleh dewan komisaris dalam suatu perusahaan selama periode waktu satu tahun. Frekuensi rapat dewan komisaris diukur dengan melihat jumlah rapat internal yang dilakukan oleh dewan komisaris perusahaan dalam jangka waktu satu tahun (Brick dan Chidambaran, 2007). 


\section{Kualitas Auditor (X7)}

Kualitas auditor merupakan salah satu faktor penting yang sangat berpengaruh terhadap pengungkapan risiko di perusahaan. Karena dengan adanya kualitas auditor yang baik maka perusahaan juga akan mengungkapkan risiko yang dihadapi dengan lebih baik pula. Kualitas auditor eksternal suatu perusahaan diukur dengan variabel dummy, yaitu dengan melakukan pengkodean. Apabila perusahaan diaudit oleh KAP lokal yang berafiliasi dengan Big Four maka diberi kode 1 , namun jika perusahaan diaudit oleh perusahaan yang tidak internasional (non-Big Four) maka diberi kode 0. KAP Big Four merupakan kantor akuntan publik besar dan tersebar di seluruh negara, lain halnya dengan KAP non-Big Four yang merupakan kantor akuntan publik kecil yang beroperasi secara domestik.

\section{Model Analisis Regresi}

Metode analisis yang digunakan untuk menguji faktor-faktor yang mempengaruhi luas pengungkapan risiko dalam penelitian ini adalah analisis regresi berganda. Berikut adalah model empiris yang digunakan dalam penelitian :

$$
\begin{aligned}
\text { RISK }_{\mathrm{t}}= & \beta_{0 \mathrm{t}}+\beta_{1} \mathrm{LEV}_{\mathrm{t}}+\beta_{2} \text { SIZE }_{\mathrm{t}}+\beta_{3} \text { INDS }_{\mathrm{t}}+\beta_{4} \text { KOMITE }_{\mathrm{t}}+\beta_{5} \mathrm{JDK}_{\mathrm{t}}+\beta_{6} \text { FRDK }_{\mathrm{t}}+ \\
& \beta_{7} \mathrm{KU}_{\mathrm{t}}+\mathrm{e}_{\mathrm{t}}
\end{aligned}
$$

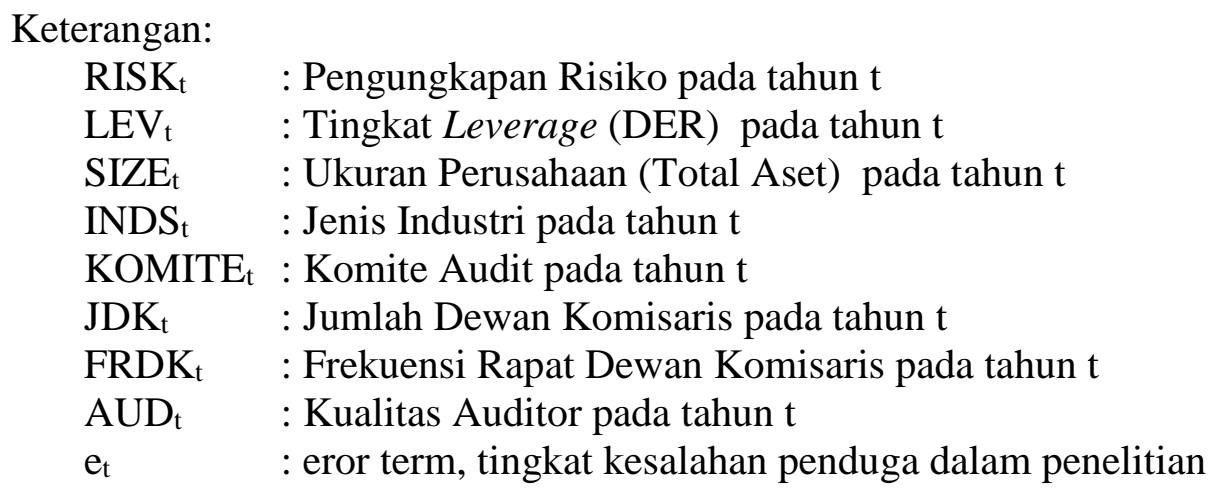

\section{HASIL DAN PEMBAHASAN}

\section{Statistik Deskriptif}

Tabel 4.1 menampilkan statistik deskriptif variabel-variabel penelitian. Data awal berjumlah 1.072 perusahaan, setelah dilakukan uji asumsi klasik terdapat cukup banyak data yang tidak normal sehingga data yang diperoleh secara normal sebesar 568 perusahaan.

Tabel 4.1

Statistik Deskriptif

\begin{tabular}{|l|r|r|r|r|r|}
\hline & N & Minimum & Maximum & Mean & Std. Deviation \\
\hline RISK & 568 & 0,08 & 0,41 & 0,25 & 0,07 \\
\hline LEV & 568 & 0,00 & 6,17 & 1,02 & 0,87 \\
\hline SIZE & 568 & 24,57 & 31,67 & 28,19 & 1,39 \\
\hline KOMITE & 568 & 1,00 & 5,00 & 3,00 & 0,26 \\
\hline JDK & 568 & 2,00 & 9,00 & 3,80 & 1,42 \\
\hline FRDK & 568 & 1,00 & 11,00 & 4,99 & 1,97 \\
\hline AUD & 568 & 0,00 & 1,00 & 0,32 & 0,47 \\
\hline INDS & 568 & 0,00 & 1,00 & 0,42 & 0,49 \\
\hline Valid N (listwise) & 568 & & & & \\
\hline
\end{tabular}


Pengungkapan risiko memiliki rata-rata sebesar 0.252529 atau 25\%. Hasil ini menunjukan bahwa dalam satu periode yang terdapat di laporan tahunan, perusahaan dalam sampel penelitian telah mengungkapkan sebanyak 25\% mengenai pengungkapan risiko. Indeks pengungkapan terkecil adalah 0.0811 yang dimiliki oleh perusahaan PT Dyandra Media International Tbk. (DYAN) tahun 2016 dan indeks pengungkapan terbesar adalah 0,4054 yang dimiliki oleh (BCAP) tahun 2015 .

Leverage menunjukan seberapa besar hutang yang dimiliki perusahaan dibanding dengan modal sendiri yang dimilikinya. Perhitungan variabel ini menunjukan nilai minimun sebesar 0,004 yang dimiliki oleh perusahaan Lippo Securities Tbk (LPPS) dan nilai maksimum sebesar 6,168 yang dimiliki oleh perusahaan Intan Baruprana Finance Tbk (IBFN). Tabel 4.1 menunjukan bahwa rata-rata leverage sebesar 1,02236. Hal ini menunjukan bahwa dalam aktivitasnya perusahaan banyak menggunakan sumber hutang daripada modal sendiri yang rata-rata mencapai 1,02236 hutang yang lebih besar dari modal sendiri yang dimiliki perusahaan. Perusahaan yang memiliki tingkat leverage yang tinggi memiliki kinerja yang buruk karena perusahaan tidak dapat membiayai kegiatan operasionalnya dengan modal sendiri, sehingga perusahaan membutuhkan dari pihak eksternal atau kreditur (Irawati, 2013).

Variabel ukuran perusahaan pada penelitian diukur dengan menggunakan log of natural total assets. Hasil perhitungan dalam variabel ini menunjukan nilai minimum 24,5670 yang terdapat pada perusahaan Danasupra Erapacific Tbk (DEFI) di tahun 2013. Jika total asetnya dirupiahkan maka hasilnya $\mathrm{Rp}$ 46.701.674.122,- Berdasarkan kriteria ukuran perusahaan yang diatur UU No 20 Tahun 2008. Maka, Danasupra Erapacific Tbk termasuk perusahaan menengah, karena memiliki total aset antara 500 juta sampai 10. Sedangkan nilai maksimum adalah sebesar 31,6702 yang terdapat pada perusahaan Sinar Mas Multiartha Tbk (SMMA) di tahun 2015. Jika dirupiahkan, maka total asetnya adalah Rp 56.778.071.000.000,- Nilai ratarata ukuran perusahaan adalah sebesar 28,186127 . Artinya rata-rata perusahaan yang menjadi sampel penelitian memiliki total aset sebesar Rp 1.748.885.773.000,- dan termasuk golongan perushaan besar (total aset $>10 \mathrm{M}$ ). Sehingga dapat disimpulkan bahwa modal yang ditanamkan dalam bentuk aset oleh perusahaan dalam penelitian ini besar.

Variabel komite audit diukur dengan menghitung jumlah anggota komite audit. Jumlah komite audit terkecil adalah 1 orang dan jumlah komite audit terbesar adalah 5 orang, sedangkan rata-rata jumlah komite audit dalam penelitian ini adalah 3 orang. Hal ini menunjukan bahwa rata-rata perusahaan dalam penelitian ini sudah memenuhi syarat Keputusan Peraturan Otoritas Jasa Keuangan Nomor 55 /POJK.04/2015 pasal 4 yaitu komite audit paling sedikit terdiri dari 3 anggota.

Variabel jumlah dewan komisaris diukur dengan menghitung jumlah seluruh dewan komisaris yang dimiliki oleh perusahaan. Hasil dari jumlah dewan komisaris dalam penelitian ini memiliki jumlah terendah yaitu 2 orang dan jumlah tertinggi yaitu 9 orang dengan ratarata jumlah dewan komisaris seluruh perusahaan adalah 3 sampai 4 orang.

Selanjutnya variabel frekuensi rapat dewan komisaris, memiliki nilai minimun adalah satu kali rapat dan memiliki nilai maksimum 11 kali rapat. Semakin sering dewan komisaris menyelenggarakan rapat, maka semakin baik kinerja perusahaan. Nilai rata-rata frekuensi rapat dewan komisaris adalah 4,99. Maka, dapat dikatakan dewan komisaris perisahaan sampel dalam penelitian ini rata-rata menyelenggarakan 4 sampai 5 kali rapat dalam setahun (rapat internal). 
Berdasarkan tabel 4.2, jumlah perusahaan yang diaudit oleh KAP yang berafiliasi dengan KAP Big 4 adalah 32,4\% atau 184 perusahaan. Sedangkan perusahaan yang diaudit oleh KAP non Big 4 adalah 67,6\% atau 384 perusahaan. Hal tersebut menunjukan bahwa rata-rata perusahaan sampel dalam penelitian ini lebih banyak menggunakan jasa audit dari KAP Non Big 4 dari pada jasa audit dari KAP Big 4. Dengan standar deviasi sebesar 0,47.

Tabel 4.2 Kualitas Auditor

\begin{tabular}{|r|r|r|r|}
\hline Frequency & \multicolumn{1}{|c|}{ Percent } & Valid Percent & \multicolumn{1}{|c|}{$\begin{array}{c}\text { Cumulative } \\
\text { Percent }\end{array}$} \\
\hline 384 & 67,6 & 67,6 & 67,6 \\
\hline 184 & 32,4 & 32,4 & 100,0 \\
\hline 568 & 100,0 & 100,0 & \\
\hline
\end{tabular}

Variabel jenis industri menggunakan variabel dummy, dimana perusahaan yang berada dalam industry high profile akan diberi skor satu (1). Sedangkan, perusahaan yang berada dalam industri low profile akan diberi skor nol (0). Dari tabel 4.3 di atas dapat dilihat bahwa perusahaan low profile dalam sampel penelitian berjumlah 326. Sedangkan perusahaan high profile berjumlah 242 . Sebesar $57,4 \%$ perusahaan yang menjadi sampel dalam penelitian merupakan perusahaan yang dalam aktivitas operasi yang lebih sederhana sehingga tingkat toleransi kegagalan lebih tinggi dan jauh dari sorotan masyarakat. Sisanya 42,6\% merupakan perusahaan yang berada pada tingkat sensitivitas tinggi terhadap lingkungan dan memiliki tingkat persaingan yang berat.

Tabel 4.3 Jenis Industri

\begin{tabular}{|c|l|r|r|r|r|}
\hline \multicolumn{2}{|c|}{} & Frequency & \multicolumn{1}{|c|}{ Percent } & Valid Percent & \multicolumn{2}{|c|}{$\begin{array}{c}\text { Cumulative } \\
\text { Percent }\end{array}$} \\
\hline \multirow{3}{*}{ Valid } &, 00 & 326 & 57,4 & 57,4 & 57,4 \\
\cline { 2 - 6 } & 1,00 & 242 & 42,6 & 42,6 & 100,0 \\
\cline { 2 - 6 } & Total & 568 & 100,0 & 100,0 & \\
\hline
\end{tabular}

\section{Pengujian Hipotesis}

Setelah melalui serangkaian uji asumsi klasik, jumlah observasi yang tersisa untuk pengujian hipotesis adalah 568. Hasil pengujian hipotesis selengkapnya dapat dilihat pada tabel 4.4 .

\section{Leverage dan Luas Pengungkapan Risiko}

Hipotesis pertama dalam penelitian ini adalah leverage berpengaruh positif terhadap pengungkapan risiko. Nilai signifikansi dari pengujian regresi hipotesis pertama adalah 0,282 $>0,05$ ini berarti leverage tidak berpengaruh terhadap pengungkapan risiko. Sehingga dapat disimpulkan bahwa hipotesis pertama dalam penelitian ini ditolak.

Dalam penelitian ini teori agensi yang diungkapkan oleh Amran et al., (2009) yang menyebutkan bahwa perusahaan yang memiliki tingkat hutang tinggi pada struktur modal dapat memaksa perusahaan untuk mengungkapkan informasi lebih banyak, tidak terbukti. Perusahaan dengan tingkat leverage yang tinggi kemungkinan besar akan mengalami pelanggaran terhadap kontrak hutang. Oleh karena itu, perusahaan cenderung akan 
melaporkan risiko dalam jumlah yang sedikit untuk mengurangi tingkat keraguan kreditur berkaitan dengan pelunasan hutang dan bunganya.

Hasil ini mendukung penelitian dari Syaifurakhman dan Herry (2016) dan Taures (2011) yang menyimpulkan bahwa leverage tidak berpengaruh terhadap pengungkapan risiko. Sedangkan penelitian ini tidak mendukung penelitian dari Oliveira et al., (2011), Utomo dan Chariri (2014) serta Yunifa (2017) yang menunjukan hasil bahwa leverage berpengaruh positif terhadap pengungkapan risiko.

Tabel 4.4

Hasil Pengujian Hipotesis

\begin{tabular}{|c|c|c|c|c|c|c|c|}
\hline & \multirow{2}{*}{$\begin{array}{c}\text { Expected } \\
\text { sign }\end{array}$} & \multicolumn{2}{|c|}{$\begin{array}{c}\text { Unstandardized } \\
\text { Coefficients }\end{array}$} & \multirow{2}{*}{ S } & Sig & $\begin{array}{c}\text { Sig } \\
(\boldsymbol{\alpha} / \mathbf{2})\end{array}$ & Hasil \\
\cline { 3 - 8 } & & $\mathbf{B}$ & S.E & & & & \\
\hline (Constant) & & $-0,077$ & 0,070 & $-1,096$ & 0,273 & 0,137 & \\
\hline LEV & + & 0,002 & 0,003 & 0,579 & 0,563 & 0,282 & Ditolak \\
\hline SIZE & + & 0,008 & 0,002 & 3,398 & 0,001 & 0,000 & Diterima \\
\hline INDS & + & $-0,008$ & 0,006 & $-1,494$ & 0,136 & 0,068 & Ditolak \\
\hline KOMITE & + & 0,024 & 0,011 & 2,200 & 0,028 & 0,014 & Diterima \\
\hline JDK & + & 0,000 & 0,002 & $-0,230$ & 0,818 & 0,409 & Ditolak \\
\hline FRDK & + & 0,004 & 0,001 & 2,806 & 0,005 & 0,002 & Diterima \\
\hline AUD & + & 0,022 & 0,007 & 3,350 & 0,001 & 0,000 & Diterima \\
\hline
\end{tabular}

\section{Ukuran Perusahaan dan Luas Pengungkapan Risiko}

Hipotesis kedua memprediksi bahwa ukuran perusahaan berpengaruh positif terhadap pengungkapan risiko. Nilai signifikansi pengujian regresi hipotesis kedua sebesar $0,000<$ 0,05 artinya ukuran perusahaan berpengaruh positif terhadap pengungkapan risiko, sehingga secara empiris hipotesis kedua diterima.

Hal ini sesuai dengan teori keagenan, perusahaan besar akan mengungkapkan informasi risiko yang lebih banyak dengan tujuan selain untuk memuaskan para pengguna laporan keuangan juga untuk mengurangi biaya keagenan serta untuk mengurangi asimetri informasi. Perusahaan yang besar akan menanggung biaya agensi yang lebih tinggi karena dengan kompleksitas usaha yang dimiliki oleh perusahaan akan menimbulkan dampak yang lebih besar terhadap masyarakat maupun lingkungannya. Selain itu, semakin besar ukuran perusahaan berarti semakin meningkat pula jumlah stakeholder yang terlibat didalamnya. Dengan keterlibatan jumlah stakeholder tersebut, maka kewajiban pengungkapan menjadi lebih besar untuk memenuhi kebutuhan stakeholder (Amran et al., 2009). Wardhana (2013) juga mengatakan bahwa perusahaan dengan ukuran lebih besar akan lebih terlihat dan menarik perhatian dari para stakeholder sehingga perusahaan akan menganggap bahwa pengungkapan risiko sebagai cara untuk meningkatkan reputasi perusahaan melalui sistematika pengungkapan.

Hasil penelitian ini mendukung hasil penelitian Al-Shammari, (2014), Yunifa (2017) dan Wardhana (2013) yang meneliti mengenai pengaruh ukuran perusahaan terhadap pengungkapan risiko menunjukan hasil bahwa ukuran perusahaan berpengaruh positif terhadap pengungkapan risiko. Sedangkan hasil penelitian ini tidak mendukung penelitian 
Doi dan Harto (2014) serta Agustina dan Ratmono (2014) yang menunjukan bahwa ukuran perusahaan berpengaruh positif terhadap pengungkapan risiko.

\section{Jenis Industri dan Luas Pengungkapan Risiko}

Hipotesis ketiga dalam penelitian ini adalah jenis industri berpengaruh positif terhadap pengungkapan risiko. Berdasarkan tabel 4.11 hasil pengujian dalam penelitian ini menunjukan nilai signifikansi sebesar 0,068 $<0,05$ dan koefisien regresi jenis industri sebesar -0,008. Artinya bahwa jenis industri tidak berpengaruh terhadap pengungkapan risiko, sehingga hipotesis ditolak.

Hasil penelitian ini konsisten dengan penelitian yang dilakukan oleh Wardhana (2013) yang mengatakan bahwa jenis industri tidak berpengaruh terhadap pengungkapan risiko. Hasil yang tidak signifikan ini disebabkan oleh pembagian jenis industri, yang di dalam satu sektor dibagi menjadi beberapa sektor lagi. Menurut Aljifri dan Hussainey (2007) dalam Wardhana (2013) hal ini membuat sektor-sektor tersebut memiliki regulasi yang berbeda terkait dengan pengungkapan informasi meskipun dalam satu tipe sektor.

Hasil ini mendukung penelitian yang dilakukan oleh Utomo dan Chariri (2014) serta Wardhana (2013) yang mengatakan bahwa jenis industri tidak berpengaruh terhadap pengungkapan risiko. Sedangkan penelitian ini tidak mendukung penelitian Taures (2011), Amran et al., (2009) dan Al-Shammari (2014) yang menunjukan hasil bahwa jenis industri berpengaruh positif terhadap pengungkapan risiko.

\section{Komite Audit dan Luas Pengungkapan Risiko}

Variabel independen komite audit dalam penelitian diprediksi memiliki pengaruh positif terhadap pengungkapan risiko. Sedangkan hasil penelitian variabel komite audit ini yang menunjukan nilai signifikansi sebesar 0,014. Nilai signifikansi tersebut lebih besar dari 0,05 sehingga komite audit berpengaruh positif terhadap pengungkapan risiko, artinya hipotesis keempat dalam penelitian ini diterima.

Menurut Mokhtar dan Mellett (2013) dalam implementasi teori keagenan, menyatakan bahwa komite audit sebagai komite penunjang dewan komisaris diperkirakan dapat mempengaruhi praktik pengungkapan risiko perusahaan. Kinerja dewan komisaris sebagai badan pengawas akan menjadi semakin baik dengan adanya kinerja komite audit yang baik. Sehingga dengan semakin besar jumlah komite audit maka semakin baik pula pengawasan yang dilakukan atas luas informasi yang diungkapkan dalam laporan tahunan.

Hasil ini mendukung penelitian yang dilakukan oleh Oktarina (2015) dan Syaifurakhman (2016) yang menyimpulkan bahwa komite audit berpengaruh terhadap pengungkapan risiko. Sedangkan penelitian ini tidak mendukung penelitian Utomo dan Chariri (2014), Mubarok dan Rohman (2013) dan Elzahar dan Hussainey (2012) yang menunjukan komite audit tidak berpengaruh positif terhadap pengungkapan risiko.

\section{Ukuran Dewan Komisaris dan Luas Pengungkapan Risiko}

Ukuran Dewan Komisaris menggunakan jumlah anggota yang duduk dalam jajaran Dewan Komisaris. Hipotesis lima memprediksi bahwa jumlah dewan komisaris berpengaruh positif terhadap pengungkapan risiko. Hasil nilai signifikansi yang diperoleh yaitu 0,409 > 0,05. Hal ini menunjikan bahwa hipotesis ditolak, tidak terdapat pengaruh antara jumlah dewan komisaris terhadap pengungkapan risiko.

Abeysekera (2008) dalam Suhardjanto et al., (2012) meneliti bahwa jumlah komisaris dapat dinilai efektif jika berada pada rentang antara lebih dari lima orang dan kurang dari 14 
orang. Dalam statisik deskriptif menunjukan bahwa rata-rata jumlah dewan komisaris dalam penelitian ini kecil hanya 3 sampai 4 orang, hal ini kemungkinan menyebabkan hasil yang tidak signifikan. Ukuran dewan komisaris yang kecil mengalami kekurangan keahlian dan membuat biaya keagenan cukup tinggi, sehingga mempengaruhi kemampuan dewan dalam memenuhi tanggung jawab tata kelola perusahaan (Bassett et al., 2007 dalam Mokhtar dan Mellett, 2013).

Walaupun hipotesis lima ditolak, hasil ini konsisten dengan Agustina dan Ratmono (2014) serta Elzahar dan Hussainey (2012). Namun tidak konsisten dengan penelitian Suhardjanto et al., (2012), Syaifurakhman (2016) dan Wicaksono (2017) yang menemukan bahwa jumlah dewan komisaris berpengaruh positif terhadap pengungkapan risiko.

\section{Pengaruh Frekuensi Rapat Dewan Komisaris Terhadap Luas Pengungkapan Risiko}

Hipotesis enam memprediksi pengaruh frekuensi rapat dewan komisaris terhadap pengungkapan risiko. Hasil pengujian menunjukan bahwa frekuensi rapat dewan komisaris berpengaruh positif terhadap pengungkapan risiko dengan tingkat signifikansi kurang dari $5 \%$. Ini artinya semakin besar frekuensi rapat dewan komisaris dalam perusahaan maka semakin baik pula pengungkapan mengenai risiko yang ada di dalam laporan tahunan. Dengan dimikian, hipotesis enam diterima.

Sebagai salah satu bentuk badan pengawas, dengan adanya rapat yang sering dilakukan oleh dewan komisaris maka memberikan lebih banyak waktu untuk mendiskusikan dan melakukan pelaksanaan tata kelola perusahaan termasuk pengungkapan risiko didalamnya. Rapat dewan komisaris merupakan salah satu ruang yang intensif untuk mengarahkan, memantau dan mengevaluasi pelaksanaan kebijakan strategis (Suhardjanto et al., 2012). Rapat dewan komisaris yang diadakan secara berkala dan berbobot mampu memberikan nilai tambah bagi perusahaan, melalui rapat tersebut dewan komisaris dapat membicarakan serta mendiskusikan informasi-informasi apa saja yang harus disajikan dalam laporan tahunan. Salah satu informasi yang disajikan adalah informasi terkait dengan risiko yang dihadapi perusahaan, sehingga informasi tentang risiko dalam laporan tahunan akan semakin meningkat seiring dengan meningkatnya frekuensi rapat dewan komisaris. Hasil pengujian regresi ini konsisten dengan penelitian Suhardjanto et al., (2012) serta Utomo dan Chariri (2014).

\section{Pengaruh Kualitas Auditor Terhadap Luas Pengungkapan Risiko}

Hipotesis ketujuh memprediksi kualitas auditor terhadap pengungkapan risiko. Nilai signifikansi dari pengujian hipotesis ketujuh adalah sebesar $0,000<0,05$, ini menunjukan bahwa hipotesis diterima. Artinya, kualitas auditor berpengaruh positif terhadap pengungkapan risiko.

Hasil pengujian ini konsisten dengan hasil penelitian yang dilakukan oleh Oliveira et al., (2011), Al-Shammari (2014) serta Mokhtar dan Mellett (2013) yang menyatakan bahwa adanya pengaruh signifikan positif antara kualitas auditor dengan pengungkapan risiko. Hasil yang signifikan ini sejalan dengan teori keagenan, yang menyatakan bahwa perusahaan audit yang besar cenderung untuk memberikan jaminan lebih kepada pemegang saham sehingga akan mengurangi biaya pemantauan yang dikeluarkan oleh prinsipal (Mokhtar dan Mellett, 2013). Jaminan yang dimaksud tersebut adalah kualitas dan luasnya pengungkapan informasi perusahaan yang mencakup pengungkapan risiko. 


\section{SIMPULAN DAN SARAN}

\section{Simpulan}

Berdasarkan hasil analisis regresi dapat ditarik kesimpulan beberapa kesimpulan sebagai berikut:

1. Leverage tidak berpengaruh terhadap pengungkapan risiko.

2. Ukuran perusahaan memiliki pengaruh positif terhadap pengungkapan risiko.

3. Jenis industri tidak berpengaruh terhadap pengungkapan risiko.

4. Komite audit berpengaruh positif terhadap pengungkapan risiko.

5. Jumlah dewan komisaris berpengaruh positif terhadap pengungkapan risiko.

6. Frekuensi rapat dewan komisaris memiliki berpengaruh positif terhadap pengungkapan risiko.

7. Kualitas auditor berpengaruh positif terhadap pengungkapan risiko.

\section{Saran}

Setelah menganalisis hasil penelitian ini, maka saran yang dapat diberikan penulis bagi penelitian selanjutnya adalah sebagai berikut: penelitian selanjutnya disarankan untuk menambahkan variabel-variabel lain yang diduga mampu mempengaruhi pengungkapan risiko dalam laporan tahunan, misalnya profitabilitas dan likuiditas. Hal ini guna meningkatkan nilai koefisien determinasi model penelitian.

\section{DAFTAR PUSTAKA}

Abeysekera, I. 2008. The role of corporate governance in intellectual capital disclosure in Kenyan listed firms. Diunduh dari www.ssrn.com..

Agustina, C. H., dan D. Ratmono. 2014. Pengaruh Kompetisi, Corporate Governance, Struktur Kepemilikan Terhadap Pengungkapan Risiko. Diponegoro Journal of Accounting $3: 1-13$.

Al-Shammari, B. 2014. Kuwait Corporate Characteristic and Level of Risk Disclosure: A Content Analysis Approach. Journal of Contemporary Issues in Business Research 3(3) :128-153.

Amran, A., A.M. Rosli, dan B. Hassan. 2009. Risk reporting An exploratory study on risk management disclosure in Malaysian annual reports. Managerial Auditing Journal $24(1): 39-57$.

Bank Indonesia. 2006. Peraturan Bank Indonesia No. 8/14/PBI/2006. Tentang Perubahan Atas Peraturan Bank Indonesia Nomor 8/4/PBI/2006 Tentang Pelaksamaam Good Corporate Governance Bagi Bank Umum. Diunduh dari : http://peraturan.go.id/inc/view/11e44c4f885a61508599313232323030.html

Bank Indonesia. 2012. Peraturan Bank Indonesia No. 14/14/PBI/2012. Tentang Transparansi dan Publikasi Laporan Bank. Diunduh dari : http://www.bi.go.id/id/peraturan/perbankan/Documents/7ed01062d1ca44a89211259eab 989036PBINo14_14_PBI_2012.pdf 
Bapepam. 2000. Keputusan Ketua Bapepam No. SE-03/PM/2000. Tentang Keberadaan dan Peran Komite Audit dalam Rangka Implementasi Good Corporate Governance. Diunduh dari : http://www.knkg-indonesia.org/dokumen/Pedoman-Komite-Audit.pdf

Bapepam. 2004. Keputusan Ketua Bapepam No. Kep-29/PM/2004 Tentang Pembentukan dan Pedoman Pelaksanaan Kerja Komite Audit. Diunduh dari : http://fekool.blogspot.co.id/2016/05/corporate-governance-komite-audit.html

Brick, E.I. and Chidambaran, N.K. 2007. Board Meetings, Committee Structure and Firm Performance. http://papers.ssrn.com. (Diakses tanggal 11 November 2010).

BUMN. 2002. Keputusan menteri BUMN No. Kep-103/MBU/2002. Tentang Pembentuan Komite Audit Bagi Badan Usaha Milik Negara. Diunduh dari : http://www.bphn.go.id/data/documents/02kmbumn103.pdf

Dalton, D. R., Daily, C. M., Johnson, J. L., dan A. Ellstrand. 1999. Number Of Directors And Financial Performance: A Meta-Analysis. The Academy of Management Journal 42(6) : 674-686.

Doi, C. J., dan P. Harto. 2014. Analisis Pengaruh Karakteristik Perusahaan Terhadap Pengungkapan Risiko. Diponegoro Journal of Accounting 3(2) : 1-11.

Elzahar, H., dan K. Hussainey. 2012. Determinants of Narrative Risk Disclosures in UK interim reports. The Journal of Risk Finance, 13(2) : 133-147.

Ikatan Akuntan Indonesia. 2014. PSAK No. 60 Instrumen Keuangan : Pengungkapan. Diunduh dari : http://www.warsidi.com/2015/12/psak-60-instrumen-keuanganpengungkapan.html

Irawati, T. 2013. Faktor-Faktor yang mempengaruhi Risk Disclosure Dengan Pendekatan Stakeholder Theory Pada Perusahaan Manufaktur Di Bursa Efek Indonesia. Jurnal Ilmiah SINUS 27-34.

Jensen, M. C., dan W. Meckeling. 1976. Theory of the Firm : Managerial Behavior , Agency Costs and Ownership Structure. Journal of Financial Economics 3 (4) : 305-360.

Linda. 2012. Mekanisme Corporate Governance dan Biaya Agensi. Jurnal SNA 15.

Linsley, Philip M. dan J. Philip. 2006. Risk reporting: A Study of Risk Disclosures in the Annual Reports of UK Companies. The British Accounting Review 38 : 387-404.

Mokhtar, E.S., dan H. Mellett. 2013. Competition , Corporate Governance , Ownership Structure and Risk Reporting. Managerial Auditing Journal 28(9) : 838-865.

Mubarok, A.M., dan A. Rohman. 2013. Pengaruh Karakteristik Perusahaan Dan Mekanisme Corporate Governance Terhadap Pengungkapan Risiko Dalam Laporan Keuangan Interm. Diponegoro Journal of Accounting $2: 1-15$.

Oktarina, M. 2015. Analisis Pengaruh Karakteristik Perusahaan Terhadap Pengungkapan Risiko Pada Perusahaan-Perusahaan yang Listing di BEI Tahun 2013. Skripsi, Universitas Diponegoro, Semarang, Indonesia.

Oliveira, J., L.L. Rodrigas, dan R. Craig. 2011. Risk-related disclosures by non-finance companies : Portuguese practices and disclosure characteristics. Managerial Auditing Journal 26(9) : 817-839.

Republik Indonesia. 2016. Peraturan Otoritas Jasa Keuangan No. 29/POJK.04/2016. Tentang Laporan Tahunan Emiten atau Perusahaan Publik. Lembaran Negara Republik Indonesia Tahun 2016. Otoritas Jasa Keuangan. Jakarta. 
Republik Indonesia 2015. Peraturan Otoritas Jasa Keuangan No. 55 /POJK.04/2015. Tentang Pembentukan Dan Pedoman Pelaksanaan Kerja Komite Audit. Lembaran Negara Republik Indonesia Tahun 2015. Otoritas Jasa Keuangan. Jakarta.

Suhardjanto, Djoko, Aryane Dewi, Erna Rahmawati, dan M. Firazonia. 2012. Peran Corporate Governance dalam Praktik Risk Disclosure Pada Perbankan. Jurnal Akuntansi dan Auditing 9(1) : 16-30.

Syaifurakhman, B dan L. Herry. 2016. Faktor-Faktor Yang Mempengaruhi Pengungkapan Risiko (Studi Empiris Pada Perusahaan Manufaktur Yang Terdaftar Di Bursa Efek Indonesia Tahun 2014). Diponegoro Journal of Accounting 5 : 1-12.

Taures, N.S.I. 2011. Analisis hubungan antara karakteristik perusahaan dengan pengungkapan risiko. Skripsi, Universitas Diponegoro, Semarang, Indonesia.

Utomo, Y., dan A. Chariri. 2014. Determinan Pengungkapan Risiko pada Perusahaan Nonkeuangan di Indonesia. Diponegoro Journal of Accounting 3 : 1-14.

Wardhana, A.A., dan N. Cahyonowati. 2013. Pengaruh Karakteristik Perusahaan terhadap Pengungkapan Risiko. Diponegoro Journal of Accounting 2 : 1-14.

Wicaksono, S. A. 2017. Analisis Determinan Tingkat Pengungkapan Risiko. Skripsi, Universitas Diponegoro, Semarang, Indonesia.

Yunifa, L. 2017. Analisis Pengaruh Karakteristik Perusahaan terhadap Tingkat Pengungkapan Risiko pada Perusahaan Manufaktur. Skripsi, Universitas Diponegoro, Semarang, Indonesia.

Zuhroh, D. dan Sukmawati I. P. H. 2003. Analisis Pengaruh Luas Pengungkapan Sosial dalam Laporan Tahunan Perusahaan terhadap Reaksi Investor. Simposium Nasional Akuntansi VI. 